\title{
An Experimental Investigation of Head loss through Trash Racks in Conveyance Systems
}

\author{
N.R. Josiah, H.P.S. Tissera and K.P.P. Pathirana
}

\begin{abstract}
:
Trash racks are widely used in the water conveyance systems to prevent trappings of floating and submerged debris that would cause operational problems at downstream reaches. Head loss through the trash rack is one of the key parameters in designing trash racks. The trash racks commonly used in Sri Lanka are with circular bars. The existing methods to estimate head loss through these trash racks give very wide results which make it difficult for engineers to produce reliable designs for water conveyance systems. In order to investigate this problem in detail and to develop a methodology to estimate head loss through trash racks a set of experiments was performed in open channel with trash racks by considering the variable parameters such as bar diameter, clear spacing, inclination angle and unit discharge. In this study, a new head loss equation is proposed based on the experimental findings to estimate the head loss through trash racks made up of circular bars.
\end{abstract}

Keywords: Head loss, Hydraulics, Open channel, Trash racks

\section{Introduction}

Trash racks are comprised of an array of metal bars that have been used in irrigation canals, water intakes, pumping stations and other hydraulic structures to prevent the floating and submerged debris that would cause damage and operational problems at the downstream reach of the conveyance systems. Hydraulic head loss is one of the governing parameters in designing trash racks according to the standards given by Knox [4]. Because, if the head loss through the trash rack is very high, there will be problems in water conveyance to the far downstream end. Hydraulic head loss mainly depends on the geometrical arrangement of the bars and hydraulic characteristics of the approach flow. Geometry of bars mainly considers about the bar shape, inclination angle of trash rack, bar thickness and clear spacing between bars or by combing bar thickness and spacing as blockage ratio. Blockage ratio is defined as the ratio between the area of total bars and the gross area of the trash racks. Hydraulic characteristics of the approach flow mainly consider about the approach velocity and the approach flow angle.

Further, IS 11388: 2012 [3] defines the classification of the trash racks such as end bearing, side bearing and integral types according to their constructional features and the methods of installation. End bearing type which consists of removable racks section installed by lowering the sections between side grooves provided in the trash rack structure. Side bearing type consists of removable section racks in which the individual sections are not installed between guides in the trash rack structure but are placed adjacent to each other laterally and in an inclined plane to obtain the desired area of flow. Integral type trash rack is in which the rack sections are bolted in place below water line. End bearing type trash rack made up of circular bars placed in straight, subcritical approach flow is the most commonly used type in Sri Lanka.

The existing formulations that are available to estimate the head loss through trash racks with circular bars are giving widely varying results which lead to difficulties in the production of reliable designs of trash racks in conveyance systems. Therefore, the objective of the study is to investigate the performance of existing methods of estimating head loss through trash racks and their shortcomings in detail and finally, to develop an improved methodology to accurately predict the head losses.

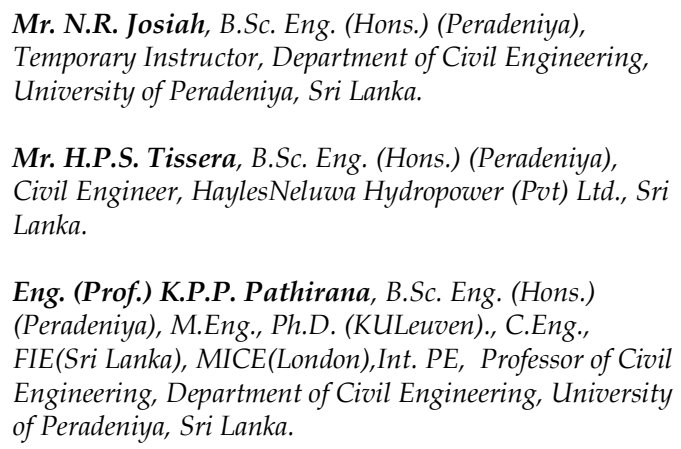

Mr. N.R. Josiah, B.Sc. Eng. (Hons.) (Peradeniya), Temporary Instructor, Department of Civil Engineering, University of Peradeniya, Sri Lanka.

Mr. H.P.S. Tissera, B.Sc. Eng. (Hons.) (Peradeniya), Civil Engineer, HaylesNeluwa Hydropower (Pvt) Ltd., Sri Lanka.

Eng. (Prof.) K.P.P. Pathirana, B.Sc. Eng. (Hons.) (Peradeniya), M.Eng., Ph.D. (KULeuven)., C.Eng., FIE(Sri Lanka), MICE(London),Int. PE, Professor of Civil Engineering, Department of Civil Engineering, University of Peradeniya, Sri Lanka. 


\section{Literature Review}

Extensive literature review was carried out in order to update the current knowledge of designing trash racks in this present study. Formulae that are applicable for designing trash racks with circular bars were found from the literature survey and presented here.

Krischmer (1926) as given in Raynalet.al [11] was one of the first authors to propose a head loss equation for inclined trash racks. This study proposed an equation (1) to estimate the head loss through trash racks only for the inclination angles ranging from $60^{\circ}$ to $90^{\circ}$ from the channel bed.

$\Delta h=K_{F}\left(\frac{b}{t}\right)^{4 / 3} \sin \alpha \cdot\left(\frac{V^{2}}{2 g}\right)$

The equation considered the variable parameters such as $K_{F}$ - bar shape factor (1.79 for circular bars), $b$ - clear spacing, $t$ - bar thickness, $\alpha$ - inclination angle with channel bed, $V$ - velocity through the trash rack and $g$ gravitational acceleration. Equation (1) can be applied to the bar shapes of airfoil, circular, rectangular bars and rectangular bars with rounded edges by appropriately changing the bar shape factor $K_{F}$.

Knox [4] suggests an equation (2) for the estimation of head losses when designing trash racks provided by the United States Army Corps of Engineers (USACE).

$\Delta h=K \frac{V^{2}}{2 g}$

where, K- bar shape factor, $V$ - approach velocity and $g$ - gravitational acceleration. Bar shape factor $K$ is formulated as a function of blockage ratio $(p)$ which is defined as the ratio of the area blocked by the bars to gross area of the trash rack. This formula is applicable for rectangular bars, rectangular bars with sharp and round edges and Circular bars. Bar shape factor for circular bar is given in Eq.(3),

$K=0.00866+0.13589 p+6.0357 p^{2}$

Another method of calculating head loss through trash racks suggested by Wahl [7] is given in Eq.(4)

$\Delta h=\left(1.45-0.45 R-R^{2}\right) \frac{V^{2}}{2 g}$

where, $V$ - approach velocity, $R=1-p, p$ blockage ratio and $g$-gravitational acceleration.
This formulation can be used for any trash rack regardless of bar shape and inclination angle of trash rack and it allows for the estimation of head losses under partially clogged conditions.

Meusburger (2002) which is referred from Raynal et.al [11] also suggested a formulation given in Eq.(5)

$\Delta h=K_{F}\left(\frac{p}{1-p}\right)^{1.5} \sin \beta\left(\frac{V^{2}}{2 g}\right)$

where, $K_{F}$ - bar shape factor, $p$ - blockage ratio, $\beta$ inclination angle from channel bed, $V$ approach velocity and g- gravitational acceleration. This formula can be applied for the bar shapes of airfoil, circular, rectangular and rectangular bars with rounded edges. Further, Raynal et.al [11] states that Meusburger (2002) used the same bar shape factors and included the term $\sin \beta$ proposed by Kirschmer (1926) without checking the relevance of those parameters.

It has also been found that several other formulae available for estimating head loss through trash racks were suggested by Clark et.al [9], Raynal et.al [11], Raynal et.al [12], Tsikata et.al [15] and Osborn (1968) which is referred in Raynal et.al [11]. They are mainly focused on trash racks with bar shapes other than circular bars. Hence, these formulae cannot be applied for the trash racks comprised of circular bars; present study has not considered those formulae.

Widely varying results were obtained when conducting the preliminary experiments and it ensures the objective of the study to proceed further. Experiment details and results are discussed in Section 3 and Section 4, respectively.

\section{Methodology}

\subsection{Experimental set-up}

All experimental runs were carried out in the Fluid mechanics laboratory of Faculty of Engineering, University of Peradeniya. Fig.1 shows a schematic diagram of the experimental set-up that was used in the experiment in order to conduct the test runs. This experiment set-up consists of intake tank, flume, trash racks, depth gauges and downstream tank with a sharp crested weir. 


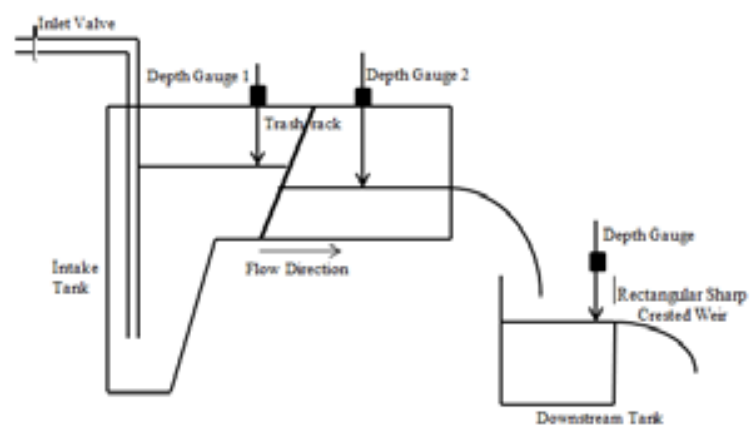

Figure 1 - Schematic view of the experimental set-up

\subsubsection{Flume}

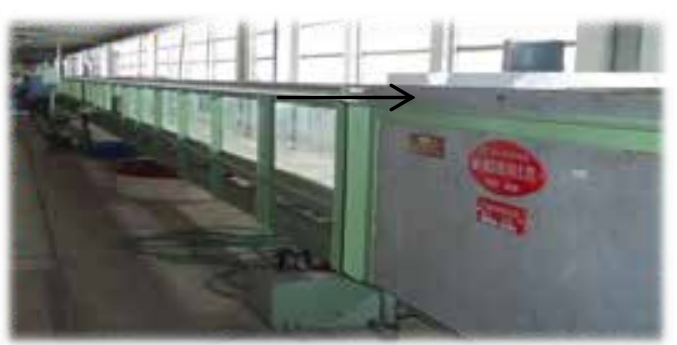

Figure 2 - View of the flume

Flume used for the experiments (see Figure 2) is $20 \mathrm{~m}$ long, $0.4 \mathrm{~m}$ wide and $0.5 \mathrm{~m}$ deep and it is attached to the $2 \mathrm{~m}$ long intake tank that consists the inlet flow controlling valves as well.

Bottom of the flume was fitted with a smooth aluminium sheet in order to reduce the effects of friction. The slope of the flume can be changed by using a motor. Further, two circular railings were mounted on top of the side walls of the channel. A trolley arrangement attached with the depth gauge was placed on top of the circular railings to measure the water depths. Least count of the depth gauges are $0.3 \mathrm{~mm}$ that ensures the accurate water depth measurements.

\subsubsection{Downstream tank}

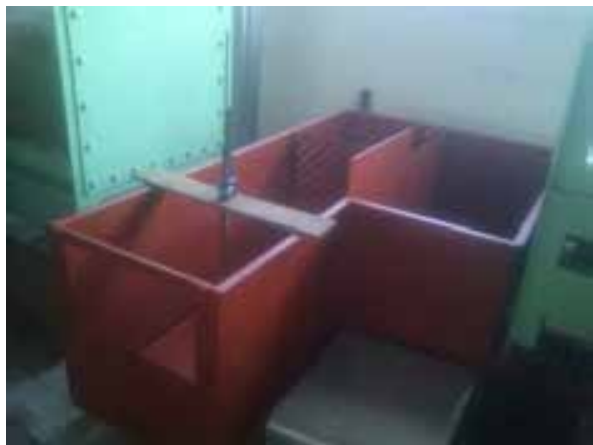

Figure 3 - Rectangular sharp crested weir
Fig.3 shows a picture of the downstream tank attached with a rectangular sharp crested weir which is placed at the downstream end of the flume. Two baffle plates have been provided in this tank in order to control water surface fluctuations through the rectangular sharp crested weir.

Further, a depth gauge arrangement is provided to measure the discharge through the flume. Least count of the depth gauge is 0.03 $\mathrm{mm}$ which ensures the accurate measurement of the water depth through the rectangular sharp crested weir.

\subsubsection{Trash racks}

Trash rack models were prepared using circular mild steel bars. Blockage ratio was considered to design the trash racks which is defined as,

Blockage ratio $=\frac{\text { Total area of the bars in Tras h rack }}{\text { Total Are a of the Channel }}(6)$

By changing the bar spacing and bar diameters of the trash racks, different blockage ratios were obtained. Table 1 gives the details of the trash rack models used in this study. Bar diameters of $2 \mathrm{~mm}, 3 \mathrm{~mm}, 6 \mathrm{~mm}, 8 \mathrm{~mm}$ and $10 \mathrm{~mm}$ were used to prepare the trash rack models and blockage ratios were varied from 0.17 to 0.68 during this study.

Table 1- Details of the fabricated trash racks

\begin{tabular}{|c|c|c|}
\hline $\begin{array}{c}\text { Bar } \\
\text { Diameter } \\
(\mathbf{m m})\end{array}$ & $\begin{array}{c}\text { Clear } \\
\text { Spacing } \\
\mathbf{( m m})\end{array}$ & $\begin{array}{c}\text { Blockage } \\
\text { Ratio }\end{array}$ \\
\hline \multirow{2}{*}{2} & 5 & 0.29 \\
\cline { 2 - 3 } & 10 & 0.17 \\
\hline \multirow{2}{*}{3} & 5 & 0.38 \\
\cline { 2 - 3 } & 10 & 0.24 \\
\hline \multirow{3}{*}{6} & 5 & 0.55 \\
\cline { 2 - 3 } & 10 & 0.39 \\
\cline { 2 - 3 } 8 & 15 & 0.30 \\
\cline { 2 - 3 } & 5 & 0.62 \\
\cline { 2 - 3 } & 10 & 0.48 \\
\hline \multirow{3}{*}{10} & 15 & 0.36 \\
\cline { 2 - 3 } & 10 & 0.68 \\
\cline { 2 - 3 } & 15 & 0.43 \\
\hline
\end{tabular}

Figure 4 shows the prepared trash rack model with a blockage ratio of 0.39 used for the experiments. 


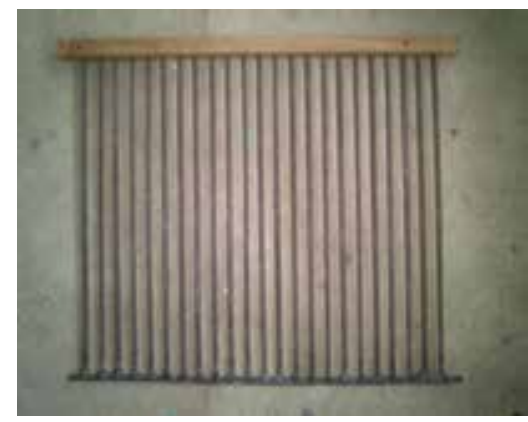

Figure 4 - Trash rack model of blockage ratio

0.39

Figure 5 shows the fixing arrangement prepared to hold the trash rack in the flume. Trash rack was placed at $7 \mathrm{~m}$ downstream of the intake tank, in order to allow the flow to be fully developed in the channel. This distance is adequate to have the fully developed flow in the channel for the discharge range considered in the experimental runs.

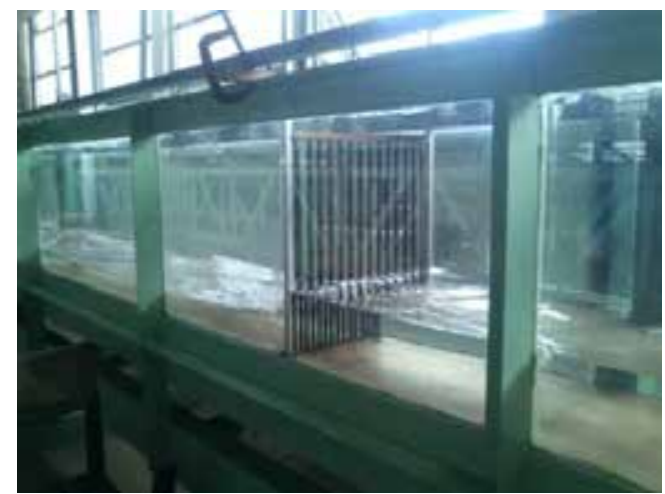

Figure 5 - Trash rack held in the flume

\subsection{Test Cases}

In this study, ten different discharges were used for each trash rack model by varying the discharge from $1 \mathrm{l} / \mathrm{s}$ to $25 \mathrm{l} / \mathrm{s}$ and inclination angle with the channel bed from $30^{\circ}$ to $90^{\circ}$ in steps of $15^{0} .13$ different trash rack models described in Table 1 were tested for each discharge and inclination angle. The total number of experimental runs conducted during this study was 650 .

\subsection{Experimental Procedure}

Inclination angle of the trash rack from channel bed, blockage ratio and the unit discharge through the flume were considered as the variable parameters in this study. First, the trash rack was placed in the flume and two depth gauges were fixed at upstream and downstream of the trash rack as shown in Fig.1. Then, the flow was passed through the flume until it becomes steady. The water depths at both upstream and downstream of the trash rack were measured. The discharge was measured by using the rectangular sharp crested weir attached to the downstream tank. Discharge was varied from lower value to higher value in steps by controlling the inlet valve. After completing the experimental run for one set, inclination of the trash rack was changed to the next angle and the same procedure was repeated. Throughout the experiments partially submerged trash rack with uniform flow condition was maintained.

When performing preliminary experiments, there were significant disturbances to the water surface when discharge increases. As a result, it caused some difficulties in measurement of water depths. In order to overcome this problem, thick rigifoam sheets were placed on the upstream water surface of the channel to reduce the water level fluctuations and to obtain a calm water surface.

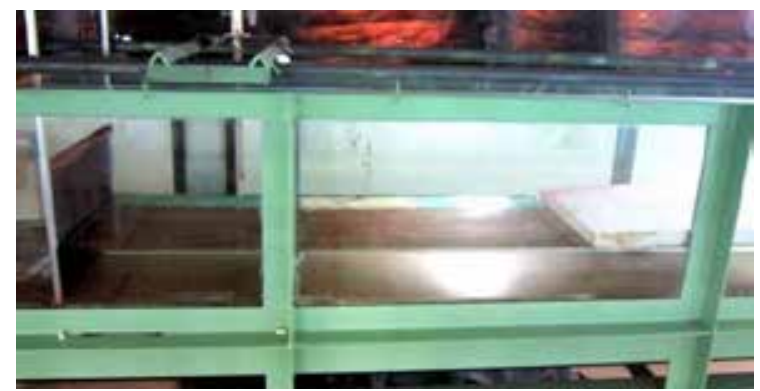

Figure 6 - Rigifoam sheets used to reduce the water level fluctuations

Figure 6 shows the calm water surface obtained upstream of the trash racks during the experiments.

\section{Results and Discussion}

The experimental data obtained for different trash rack models were analysed using various formulae suggested in previous studies. Prior to the analysis, preliminary checks were carried out to verify whether the flow is supercritical or sub critical and the effect of kinetic energy coefficient on the analysis.

\subsection{Froude Number}

Froude number is the dimensionless parameter that is used to identify the state of fluid flow; whether it is subcritical or supercritical flow. In all experimental runs, Froude numbers of the upstream of the trash rack were calculated.

$F r=\frac{V}{\sqrt{g h}}$ 
where, $V$ - approach velocity, $h$ - water depth and $g$ - gravitational acceleration. Froude numbers of the flow were found to be between 0.17 and 0.55 . It ensures that the upstream flow is subcritical.

\subsection{Effect of Kinetic Energy Coefficient}

Basic energy equation of fluid flow typically includes a coefficient of kinetic energy when estimating the velocity heads. Tsikata et.al [15] states that the equation accompanied with kinetic energy coefficients can be written in the form of Eq.8.

$\Delta h=h_{1}-h_{2}+\frac{\left(\alpha_{1} U_{1}^{2}-\alpha_{2} U_{2}^{2}\right)}{2 g}$

where, $h_{1-}$ upstream water depth, $h_{2-}$ downstream water depth, $U_{1}$ - upstream flow velocity, $U_{2}-$ downstream flow velocity and $\alpha_{1}$, $\alpha_{2}$ - kinetic energy coefficients and $g$ gravitational acceleration.

Reynolds number of the flow was calculated using the Eq.(9)in order to find out the effect of kinetic energy coefficient which was referred in Tsikata et.al [15].

$R e=\frac{V b}{v}$

where, $V$ - Flow velocity, $b$ - bar thickness and $v$ kinematic viscosity of water $\left(10^{-6} \mathrm{~m}^{2} / \mathrm{s}\right)$. Reynolds number of the flow was found to be over 1000.Hence, it can be said that according to the Tsikata et.al [15], the effect of the kinetic energy coefficient due to the fluid flow can be neglected when estimating the head losses

\subsection{Comparison of measured head losses with the head loss computed using existing equations}

Experimental data obtained from this present study were compared with the suggested equations from the previous studies. Eq.(1), (2), (4) and (5), which can be applied for trash racks comprised of circular bars were considered for the comparison study.

Comparison of the measured head losses with calculated head losses by using Krischmer (1926) is shown in Fig.7. It can be noted that for small values of discharges the calculated head loss values are somewhat agreeing with the measured head losses. However, for higher discharges the predicted head losses are deviated much more from the measured values.

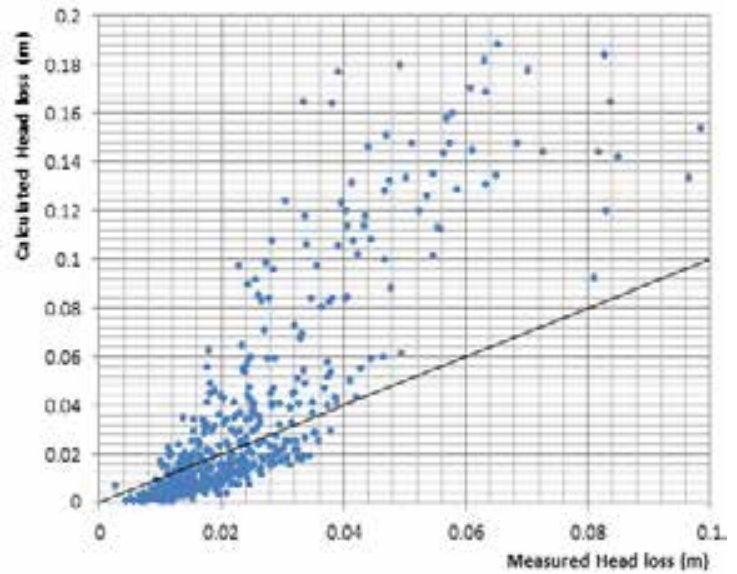

Figure 7 - Comparison of head losses computed using Krischmer (1926) with the measured head losses

Krischmer (1926) recommended to use the velocity term as the velocity through the trash rack which is practically difficult to measure but, it was estimated using other data and then applied to the formulation.

Figure 8, Figure 9 and Figure 10 show the graphs that compare the measured head losses with the head losses computed using Knox (USACE), Wahl (1992) and Meusburger (2002) formulae respectively.

It can be noted that formulae give under predicted values of head losses compared to measured head losses. Figure 8, 9 and 10 show the similar behaviour and particularly Fig.9 shows much deviation from measured head losses for the higher discharges. It could be a reason that the Eq.(4) did not consider about the effect of the inclination angle of trash racks. This formulation considered only the variables $R$ and $V$.

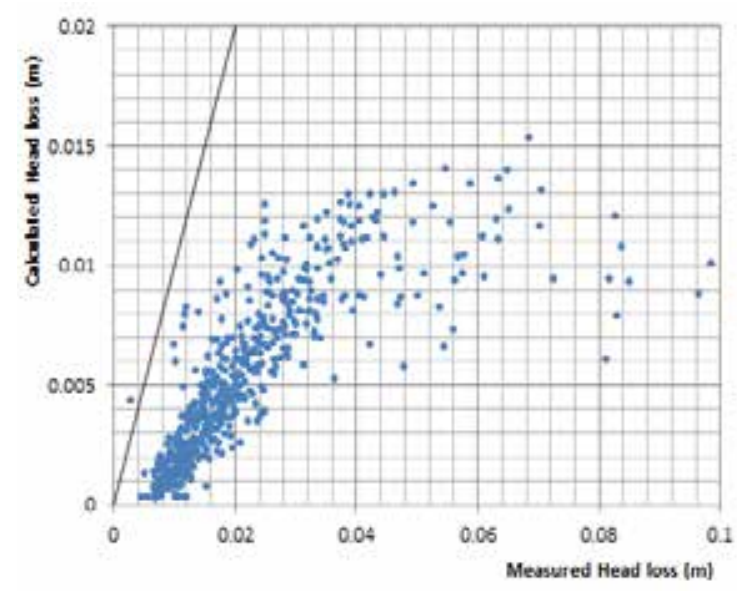

Figure 8 - Comparison of head losses computed using Knox (USACE) with the measured head losses 


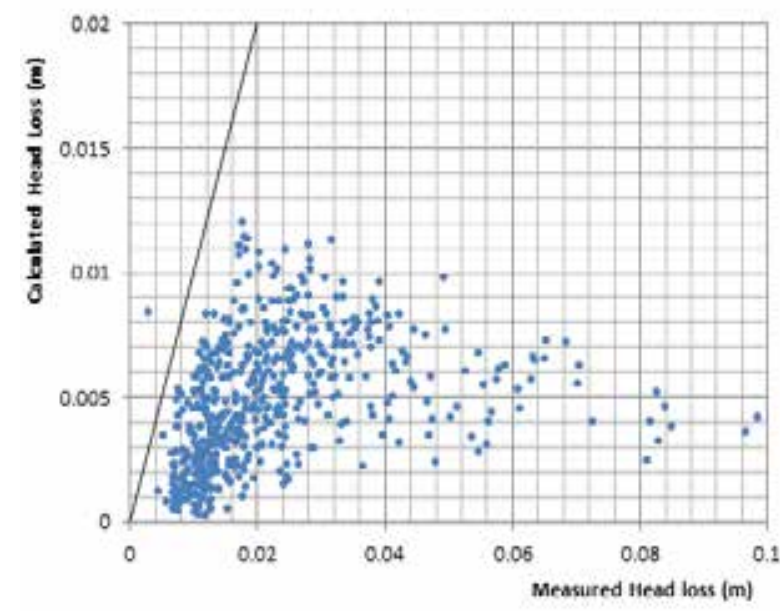

Figure 9 - Comparison of head losses computed using Wahl (1992) with the measured head losses

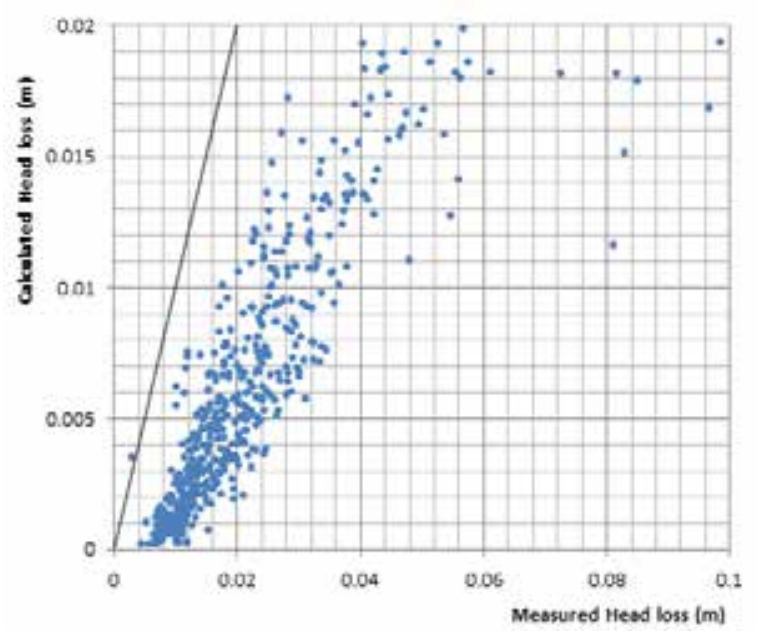

Figure 10 - Comparison of head losses computed using Meusburger (2002) with the measured head losses

\subsection{Derivation of a New Formula}

It can be seen from the comparison study that different formulae give incomparable head loss values for the same trash rack model subjected to same hydraulic parameters. Therefore, it is essential to derive a new formulation that leads to the accurate estimation of head loss through trash racks. Inclination angle of the trash rack, approach flow velocity, unit discharge, blockage ratio and gravitational acceleration were considered as governing parameters which affect the head loss through trash racks which can be expressed as a function given in Eq.(10).

$\Delta h=f(\alpha, V, q, p, g)$

where, $\alpha$-inclination angle from channel bed, $V$ - approach velocity, $q$ - unit discharge, $p$ blockage ratio and $g$ - gravitational acceleration.
By using the Buckingham's $\pi$ theorem nondimensional groups were found for the variables listed in Eq.(10). Formulated $\pi$ groups are shown in Eq.(11).

$\frac{\Delta h}{V^{2} / 2 g}=f\left(\sin \alpha, p, \frac{q g}{V^{3}}\right)$

After deriving the non-dimensional $\pi$ groups, 500data points out of 650 were selected to formulate the relationship of the head loss through trash rack and the other 150 data points were used to validate the equation. For the validation process, trash rack sets with 6 $\mathrm{mm}$ diameter bars (see Table 1) were used, which were not taken in the calibration process.

To formulate the equation, $\log$ values of the $\pi$ groups were determined and then multivariable regression analysis which is given as a built-in data analysis tool in Microsoft Excel package was applied. The relationship obtained with the regression coefficient of ( $\mathrm{R}^{2}$ value) of 0.95 , is shown in Eq.(12).

$$
\begin{aligned}
& \log \frac{\Delta h}{V^{2} / 2 g}=-0.716+0.06 \log (\operatorname{Sin} \alpha)+ \\
& 0.16 \log (p)+1.55 \log \left(\frac{q g}{V^{3}}\right)
\end{aligned}
$$

Eq.(13) shows the derived relationship between the head loss and the variable parameters by taking antilog both sides.

$\frac{\Delta h}{V^{2} / 2 g}=0.1923(\operatorname{Sin} \alpha)^{0.05}(p)^{0.15}\left(\frac{q g}{V^{3}}\right)^{1.56}$

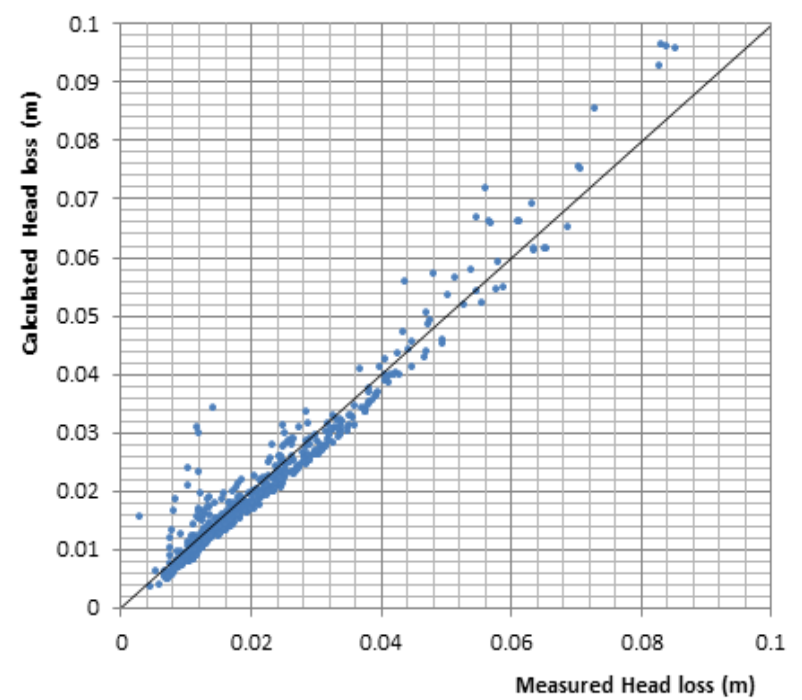

Figure 11 - Comparison of Head loss computed using newly derived equation with the measured Head losses 
Figure 11 shows the comparison of head loss computed using newly derived equation (Eq.13) with the measured head losses. It can be clearly observed that the newly formulated equation provides a better correlation with the measured head losses.

After the derivation of the new formula, it was validated with the experimental data already separated for the validation purposes. Fig.12 shows the comparison of calculated and measured head losses for model verification.

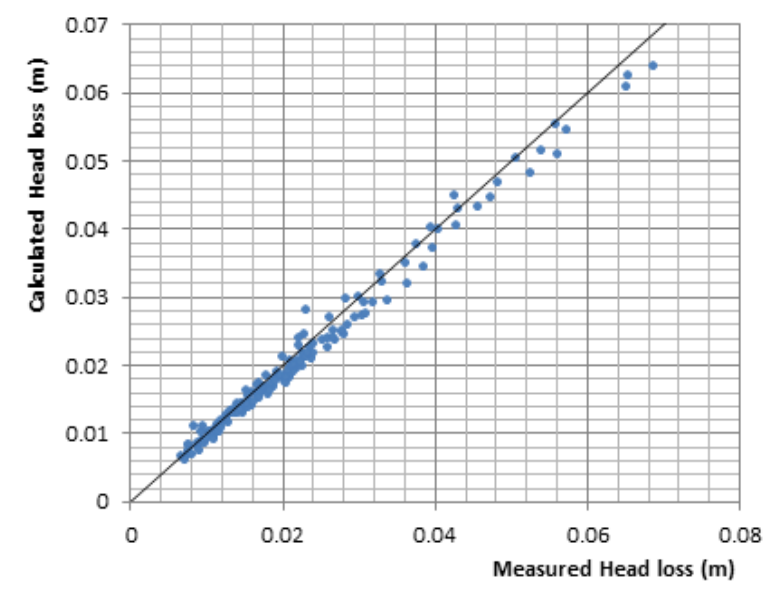

Figure 12 - Comparison of calculated and measured head losses for model verification

Mean Relative Error (MRE) and Standard Deviation $(\sigma)$ were also calculated to quantify the errors of each formulation discussed in this study. Eq.(14) and Eq.(15) show the equations that were used to calculate MRE and $\sigma$, respectively.

$M R E=\frac{1}{N} \sum_{i=1}^{N}\left(\frac{\left|\Delta h_{\text {measured }, i}-\Delta h_{\text {calculated }, i}\right|}{\Delta h_{\text {measured }, i}}\right) \ldots$

$\sigma=\sqrt{\frac{1}{N} \sum_{i=1}^{N}\left(\Delta h_{\text {measured }, i}-\Delta h_{\text {calculated }, i}\right)^{2}}$.

Table 2 shows the details of the error parameters.

Table 2- MRE and $\sigma$ of the existing equations

\begin{tabular}{|l|c|c|}
\hline Name of the Study & MRE (\%) & $\boldsymbol{\sigma}(\mathbf{m})$ \\
\hline Krischmer (1926) & 70.7 & 0.031 \\
\hline Knox (USACE) & 76.2 & 0.021 \\
\hline Wahl (1992) & 74.3 & 0.023 \\
\hline Meusburger (2002) & 73.6 & 0.019 \\
\hline Present Study & 12.5 & 0.004 \\
\hline
\end{tabular}

Sensitivity analysis also was carried out in this equation and found that the most sensitive parameter in this formulation is unit discharge $(q)$ and the least influence is given by inclination angle.

\section{Summary and Conclusions}

Trash racks made up of circular bars can be seen most commonly in irrigation canals, water supply intakes, water treatment plants and other water conveyance systems in Sri Lanka. Therefore, when designing a trash rack for a conveyance system, it is essential to predict an acceptable estimation of head loss through trash rack which is the governing parameter of designing trash racks. Therefore, the objective of the study was to suggest an improved methodology for the estimation of head loss through trash racks.

Head loss through trash racks was investigated by conducting a series of experiments by considering the parameters such as inclination angle with channel bed, approach velocity, unit discharge and blockage ratio. Blockage ratio ranges between 0.17 and 0.68 and inclination angle varied from $30^{\circ}$ to $90^{\circ}$. The proposed relationship to estimate the head loss through the trash racks is given in Eq.(13). It incorporates all possible parameters affecting the head loss through trash rack. This proposed formula proved to be giving head losses through trash racks with a reasonable accuracy.

Proposed Eq.(13) is valid only for trash racks comprised of circular bars. Experiments were conducted by using horizontal, smooth channel bed and with partially submerged trash racks in uniform, steady flow conditions.

As further studies, fully submerged condition of trash racks as well as different bar shapes can be considered in estimating the head losses through trash racks to update the formulation. The study can also be extended to incorporate the effects of bed friction and channel slope on the estimation of total head loss through trash racks. 


\section{References}

1. Chow, V. T, Open channel hydraulics, Int. Ed., McGraw- Hill book company, Singapore, 1986.

2. Douglas, J. F., Solving Problems in Fluid Mechanics - Volume 2, 3rd Ed., ELBS Longman, 1996.

3. IS 11388: 2012, Recommendations for Design of

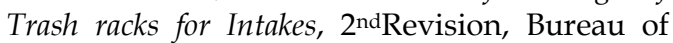
Indian Standards, Delhi, 2012.

4. Knox county Tennessee Stormwater Management Manual, Technical Guidance- Volume 2, Department of Engineering and Public Works, Knoxville, USA, 2008.

5. Massey, B., Revised by Smith, J. W., Mechanics of Fluids, $8^{\text {th }}$ Ed., Taylor and Francis publications, New York, 2001.

6. Novak, P., Moffat, A. I. B., Nalluri, C., \& Narayanan, R., Hydraulic Structures, $4^{\text {th }}$ ed., Taylor and Francis publishers, New York, 2007.

7. Wahl, T. L., Trash Control, Structures and Equipment: A literature review and survey of Bureau of Reclamation, Report No: R-92-05: 1-35, USBR, Denver Co., 1992.

8. Bozkus, Z., Cakir, P. \& Ger, M., “Energy Dissipation by Vertically Placed Screens", Canadian Journal of Civil Engineering, Vol.34, pp. 557-564, 2007.

9. Clark, S. P., Tsikata, J. M. \& Haresign, M., "Experimental Study of Energy Loss through Submerged Trash Racks", Journal of Hydraulic Research, Vol.48, No.1, pp. 113-118, 2010.

10. Fike, M., Hribernik A. \& Heribernik, T. M., (2013), "Economical Optimization of a Trash Rack Design for a Hydropower Plant", Journal of Trends in the Development of Machinery and Associated Technology, Vol.17, No.1, pp. 161-164, 2013.

11. Raynal, S., Courret, D., Chatellier, L., Larinier, M.\& David, L., "An Experimental Study on Fish Friendly Trash Racks- Part I. Inclined Trash Racks", Journal of Hydraulic Research, Vol. 51, No.1, pp. 56-66, 2013.

12. Raynal, S., Courret, D., Chatellier, L., Larinier, M.\& David, L., “An Experimental Study on Fish Friendly Trash Racks- Part 2. Angled trash Racks", Journal of Hydraulic Research, Vol. 51, No.1, pp. 67-75, 2014.

13. Raynal, S., Courret, D., Chatellier, L., Larinier, M.\& David, L., "Streamwise Bars in FishFriendly Angled Trash Racks", Journal of
Hydraulic Research, Vol.52, No.3, pp. 426-431, 2014.

14. Tsikata, J. M., Tachie, M. F. \& Katopodis, C., "Experimental Study of Turbulent Flow Near Model Trash Racks", Journal of Hydraulic Research, Vol.47, No.2, pp. 275-280, 2009.

15. Tsikata, J. M., Tachie, M. F. \& Katopodis, C., "Open Channel Turbulent Flow through Bar Racks", Journal of Hydraulic Research, Vol.52, No.5, pp. 630-643, 2014.

16. Yeh, H. H. \& Sherstha, M., "Free Surface Flow through Screen", Journal of Hydraulic Engineering, ASCE, Vol. 115, pp.1371-1385, 1989. 